Original Article

\title{
Evaluation of three alum-precipitated Aeromonas hydrophila vaccines administered to Labeo rohita, Cirrhinus mrigala and Ctenopharyngodon idella: immunokinetics, immersion challenge and histopathology
}

\author{
Avaliação de três vacinas de Aeromonas hydrophila precipitadas com alúmen \\ administradas a Labeo rohita, Cirrhinus mrigala e Ctenopharyngodon idella: \\ imunocinética, desafio de imersão e histopatologia
}

F. Sughra* ${ }^{a *}$ M. Hafeez-ur-Rahmanª, F. Abbasa ${ }^{\mathrm{a}}$, I. Altaf ${ }^{\mathrm{b}}$ (D)

aUniversity of Veterinary and Animal Sciences, Department of Fisheries and Aquaculture, Lahore, Pakistan

bUniversity of Veterinary and Animal Sciences, Quality Operations Laboratory, Lahore, Pakistan

\begin{abstract}
Aeromonas hydrophila is a cause of infectious disease outbreaks in carp species cultured in South Asian countries including Pakistan. This bacterium has gained resistance to a wide range of antibiotics and robust preventive measures are necessary to control its spread. No prior use of fish vaccines has been reported in Pakistan. The present study aims to develop and evaluate inactivated vaccines against local strain of $A$. hydrophila in Pakistan with alum-precipitate as adjuvant. The immunogenic potential of vaccine was evaluated in two Indian major carps (Rohu: Labeo rohita, Mori: Cirrhinus mrigala) and a Chinese carp (Grass carp: Ctenopharyngodon idella). Fish were vaccinated intraperitoneally followed by a challenge through immersion. Fish with an average age of 4-5 months were randomly distributed in three vaccinated groups with three vaccine concentrations of $10^{8}, 10^{9}$ and $10^{10}$ colony forming unit (CFU)/ml and a control group. Fixed dose of $0.1 \mathrm{ml}$ was applied to each fish on $1^{\text {st }}$ day and a booster dose at 15 days post-vaccination (DPV). Blood samples were collected on 14, 28, 35, 48 and 60 DPV to determine antibody titers in blood serum using compliment fixation test (CFT). Fish were challenged at $60 \mathrm{DPV}$ with infectious A. hydrophila with $10^{8} \mathrm{CFU} / \mathrm{ml}$ through immersion. Significantly higher levels of antibody titers were observed from $28 \mathrm{DPV}$ in all vaccinated groups as compared to those in the control group. In challenge experiment the average RPS (relative percent survivability) was $71 \%$ for groups vaccinated with $10^{9}$ and $10^{10} \mathrm{CFU} / \mathrm{ml}$ and $86 \%$ for $10^{8} \mathrm{CFU} / \mathrm{ml}$. Vaccine with $10^{8} \mathrm{CFU} / \mathrm{ml}$ induced highest immune response followed by $10^{9}$ and $10^{10} \mathrm{CFU} / \mathrm{ml}$. The immune response of $L$. rohita and C. idella was better than that of $C$. mrigala. In general, normal histopathology was observed in different organs of vaccinated fish whereas minor deteriorative changes were found in fish vaccinated with higher concentrations of the vaccine.
\end{abstract}

Keywords: Aeromonas hydrophila, inactivated vaccine, carp, immune response, antibody titer.

\begin{abstract}
Resumo
Aeromonas hydrophila é uma causa de surtos de doenças infecciosas em espécies de carpas cultivadas em países do sul da Ásia, incluindo o Paquistão. Essa bactéria ganhou resistência a uma ampla gama de antibióticos, e medidas preventivas robustas são necessárias para controlar sua disseminação. Nenhum uso anterior de vacinas para peixes foi relatado no Paquistão. 0 presente estudo tem como objetivo desenvolver e avaliar vacinas inativadas contra cepa local de $A$. hydrophila no Paquistão com precipitado de alúmen como adjuvante. $O$ potencial imunogênico da vacina foi avaliado em duas carpas principais indianas (Rohu: Labeo rohita, Mori: Cirrhinus mrigala) e uma carpa chinesa (Grass Carp: Ctenopharyngodon idella). Os peixes foram vacinados por via intraperitoneal, seguido de um desafio por imersão. Peixes com idade média de 4-5 meses foram distribuídos aleatoriamente em três grupos vacinados com três concentrações de vacina de $10^{8}, 10^{9}$ e $10^{10}$ unidades formadoras de colônias (UFC) / ml e um grupo de controle. Foi aplicada dose fixa de $0,1 \mathrm{ml}$ em cada peixe no $1^{\circ}$ dia e dose de reforço 15 dias pós-vacinação (DPV). Amostras de sangue foram coletadas em 14, 28, 35, 48 e 60 DPV para determinar os títulos de anticorpos no soro sanguíneo usando o teste de fixação de elogio (CFT). Os peixes foram desafiados a $60 \mathrm{DPV}$ com infecciosa $A$. hydrophila com $10^{8} \mathrm{CFU} / \mathrm{ml}$ por imersão. Níveis significativamente mais elevados de títulos de anticorpos foram observados em 28 DPV em todos os grupos vacinados, em comparação com aqueles no grupo de controle. Na experiência de desafio, o RPS médio (sobrevivência percentual relativa) foi de $71 \%$ para os grupos vacinados com $10^{9}$
\end{abstract}

*e-mail: 2017-phd-1034@uvas.edu.pk; mhafeezurehman@uvas.edu.pk

Received: March 16, 2021 - Accepted: May 3, 2021

This is an Open Access article distributed under the terms of the Creative Commons Attribution License, which permits unrestricted use, distribution, and reproduction in any medium, provided the original work is properly cited. 
e $10^{10} \mathrm{CFU} / \mathrm{ml}$ e $86 \%$ para $10^{8} \mathrm{CFU} / \mathrm{ml}$. A vacina com $108 \mathrm{UFC} / \mathrm{ml}$ induziu a maior resposta imune seguida por $10^{9}$ e $10^{10} \mathrm{UFC} / \mathrm{ml}$. A resposta imune de L. rohita e C. idella foi melhor do que a de C. mrigala. Em geral, histopatologia normal foi observada em diferentes órgãos de peixes vacinados, enquanto pequenas alterações deteriorantes foram encontradas no grupo de controle e nos peixes vacinados com concentrações mais altas da vacina.

Palavras-chave: Aeromonas hydrophila, vacina inativada, carpa, resposta imune, título de anticorpos.

\section{Introduction}

Due to high demand for fish protein, the aquaculture has attracted a lot of attention over the past three decades and has been one of the fastest growing agricultural sectors in the world (FAO, 2018). Aquaculture systems are intensified to increase fish yield, which results in higher incidence of fish diseases especially in developing countries where culture systems operate with limited financial resources, awareness and technology. Infectious diseases are the leading cause of fish mortality in aquaculture, which is predominantly caused by Aeromonas (Hamouda et al., 2019). Among all sub-species, Aeromonas hydrophila is a major cause of outbreaks in aquaculture that has prompted food insecurity and global economic losses (Dash et al., 2014; Aboyadak et al., 2015; Baumgartner et al., 2017). This bacterium causes various infections in fish predominantly haemorrhagic septicemia, dropsy, epizootic ulcerative syndrome, haemorrhagic enteritis and scarlet disease (Igbinosa et al., 2012). Aeromonad infections on fish farms are accelerated by a number of factors including variations in the physical and chemical parameters of pond water.

Vaccination represents an effective approach to control diseases in aquaculture (Ma et al., 2019). It is considered a promising measure for the prevention of infectious diseases and fish health management (Collins et al., 2019; Bedekar et al., 2020). However, commercializing A. hydrophila vaccines in fish has been a challenge due to the high diversity of its species worldwide (Dash et al., 2014). This gram-shaped rod of the family Aeromonadaceae causes symptoms of poor health including tail and skin rot and fatal anemia in several species of fish (Fernandez et al., 2014). Due to its ubiquitous presence in water, this bacterium has become a provocative fish pathogen that requires advanced pond management practices and safety measures to control it (Mzula et al., 2019). Use of antibiotics has obvious drawbacks, more predominantly, the risk to public health because of development of antimicrobial resistance. In order to reduce the use of chemicals and antibiotics in aquaculture and marine environment, the use of vaccination is suggested (Adams, 2019). Immunoprophylaxis is the stimulation of immunity in an organism against disease. Vaccines are recognized as active immunization that help to enhance the meditation of acquired antibodies. Vaccines for aquaculture have been successful in reducing the use of antibiotics especially in developed countries (Sommerset et al., 2005; Gudding and Van Muiswinkel, 2013).

To the best of our knowledge, no evidence of disease prevention and control through vaccines has been reported in culture and feral systems of Pakistan, where economic loss due to disease outbreak is evident from the literature (Shah et al., 2012). Keeping in view the increasing importance of vaccination as immunoprophylaxis measure for the development of antibodies to strengthen fish immunity, this experiment was planned to produce inactivated vaccines against pathogenic strains of A. hydrophila in cultured fish species of Pakistan. Three different concentrations of inactivated vaccine (at 108 $10^{9}$ and $10^{10} \mathrm{CFU} / \mathrm{ml}$ ) were prepared with alum-precipitate as adjuvant. A local isolate of $A$. hydrophila was used. For a 60 -day trial, a fixed dose of vaccine $(0.1 \mathrm{ml} /$ fish $)$ was used. The challenge $\left(10^{8} \mathrm{CFU} / \mathrm{ml}\right)$ was at $60 \mathrm{DPV}$ through immersion bath. Serum samples were collected on designated days during the trial and evaluation of antibody titers was performed using complement fixation test (CFT). Finally, histopathology of tissues was conducted to investigate the impact of vaccines on fish health.

\section{Material and Methods}

\subsection{Preparation of adjuvanted vaccines}

The vaccines were developed from $A$. hydrophila strain (deposited at NCBI GenBank under accession number - MT249822.1), belonging to University of Veterinary and Animal Sciences (UVAS). The organism was isolated and molecularly characterized from diseased $L$. rohita in 2018 . The pour-plate based counting technique was used to accomplish bacterial count using conventional procedure described by Larry and James (2001). The isolate was intraperitoneally injected in fish and re-isolated twice to enhance tits virulence. Brain-Heart Infusion (BHI) broth was used to grow the bacteria. After inoculation of A. hydrophila in BHI, the flasks were placed on an orbital shaker at $90 \mathrm{rpm}$ for 24 hours at $30^{\circ} \mathrm{C}$. Then $0.5 \%$ formalin was added to inactivate the culture on an orbital shaker at $100 \mathrm{rpm}$ for 24 hours at $30^{\circ} \mathrm{C}$. Inactivation of culture was verified by streaking on nutrient agar plates and incubation at $37^{\circ} \mathrm{C}$ for 48 hours. The killed cells were collected by centrifugation at 5000 rpm for 15 minutes. The cells were washed three times with sterile phosphate buffer solution (PBS, $0.1 \mathrm{M}, \mathrm{pH}$ 7.0). The cells were resuspended in sterile PBS and the concentration of cells was adjusted to $1.0 \times 10^{9}$ cells. The preparation was stored at $4^{\circ} \mathrm{C}$. In order to enhance the efficacy and life time, alum-precipitate (in the form of gel) was separately formulated and added in vaccines as adjuvant according to previously described protocols (Gupta, 1998; Vecchi et al., 2012).

From $20 \mathrm{ml}$ of bacterial culture, $8 \mathrm{ml}$ was mixed with $2 \mathrm{ml}$ of alum-precipitate to obtain vaccine (VC) with concentration of $10^{9} \mathrm{CFU}$ for $0.1 \mathrm{ml}$ dose fixed for all fish (VC $=1 \times 10^{10} \mathrm{CFU} / \mathrm{ml}$ ). In remaining $12 \mathrm{ml}$ sample, $10 \mathrm{ml}$ PBS was added to obtain a diluted sample of $22 \mathrm{ml}$. From $22 \mathrm{ml}$ diluted sample, $8 \mathrm{ml}$ sample was mixed with $2 \mathrm{ml}$ gel to obtain vaccine $\mathrm{VB}$ with potency $1 \times 10^{9} \mathrm{CFU} / \mathrm{ml}$. In remaining $14 \mathrm{ml}$ sample, $10 \mathrm{ml}$ PBS was again added to obtain further diluted sample of $24 \mathrm{ml}$. From $24 \mathrm{ml}$ diluted sample, $8 \mathrm{ml}$ 
sample was mixed with $2 \mathrm{ml}$ gel to obtain vaccine $V A$ with potency $1 \times 10^{8} \mathrm{CFU} / \mathrm{ml}$. All three vaccines (VA, VB and VC) were properly homogenized with a homogenizing mixer.

Sterility check was performed to verify vaccine safety. For this purpose, each vaccine was separately streaked on a nutrient agar plate and incubated for $72 \mathrm{hr}$ at $37^{\circ} \mathrm{C}$ to check any bacterial growth or contamination development. Sterility was further verified by inoculating the vaccines in nutrient broth tubes for 15 days and incubating at $37^{\circ} \mathrm{C}$. In this way, three (03) different vaccines VA, VB and VC were prepared and stored in glass bottles at $4^{\circ} \mathrm{C}$.

\subsection{Fish collection and placement}

Healthy fish samples (Rohu, Mori and Grass carp) with an average age of 4-5 months and weight between 250-350 grams were collected from Fish Seeds Nursery of Forest, Wildlife and Fisheries Department, situated at Manga Mandi, Lahore (GPS location: $31^{\circ} 18^{\prime} \mathrm{N}, 74^{\circ} 04^{\prime} \mathrm{E}$ ) and Government Fish Farm situated at Kacha, Lahore (GPS location: $31^{\circ} 23^{\prime} \mathrm{N}, 74^{\circ} 19^{\prime} \mathrm{E}$ ) during Aug - Sep 2020. The fish were carefully transported in oxygenated plastic bags to Fish Hatchery, UVAS Ravi Campus, Pattoki.

All samples were uniformly distributed in three (03) groups such that each group contained 24 fish (eight fish from each of the three species). A control group was also prepared having 24 samples with 8 fish from each species. Four concrete flow-through tanks $\left(126 \times 36 \times 60\right.$ inch $\left.^{3}\right)$ were reserved in Fish Hatchery, UVAS Ravi Campus, Pattoki. Three tanks were designated for trial groups whereas $4^{\text {th }}$ was designated as control group. Fish were carefully transferred to respective tanks/groups. All fish groups were first kept for 10 days to acclimatize with the tank's environment. Fish were fed twice with commercially prepared pellet feed at satiation. The water temperature was maintained at $25.8 \pm 1.5^{\circ} \mathrm{C}$ during experimental period.

\subsection{Vaccination protocol}

The experiment was designed to last for 60 days. Fish were first anaesthetized with $100 \mathrm{mg} / \mathrm{L}$ clove oil using immersion method (Neiffer and Stamper, 2009). The $1^{\text {st }}$ injection of $0.1 \mathrm{ml}$ dose was given to anesthetized fish in three (03) groups on day 1 through intraperitoneal route (I.P.), while booster dose of $0.1 \mathrm{ml}$ was given to each fish on 15 post vaccination day through intraperitoneal route (I.P.). The fish in control group were injected with equal volume of $0.85 \%$ saline at the same time.

\subsection{Serum collection}

On 14, 28, 35, 48 and 60 day post-vaccinations, blood samples were collected randomly from 12 fish (4 samples per species) in each vaccinated group as well as 4 samples from control group. In this way, 16 blood samples were obtained on each treatment. Blood samples were centrifuged at $1500 \mathrm{rpm}$ for 10 minutes. Serum was separated with the help of micropipette. Sera samples were poured in separately labeled eppendorf tubes and stored at $-20^{\circ} \mathrm{C}$ for further analysis. Antibody titer in sera was determined using complement fixation test (CFT) in 96-well plates serial two-fold dilution of each serum pool.

\subsection{Compliment Fixation Test (CFT)}

Complement fixation test (CFT) was used to estimate antibody titer in each serum sample collected from trial fish against $A$. hydrophila in 96-well plate using serial 2 -fold dilution of each serum. The test was performed using different steps that included preparation of amboceptors (rabbit) and its titration, sensitization of RBC (red blood cells) obtained from sheep blood, collection, preparation of working solution of complement (guinea pig) and its titration, heat treatment of amboceptors and immune serum samples and performing the complement fixation test (Purcell et al., 1969; Rahman et al., 2003). PBS was taken and $50 \mu$ l was added to all the wells of 96-well micro titer plate. Fish serum sample was taken and $50 \mu 1$ was added to 1st well and two-fold dilution was performed up to well number 9 . Antigen was prepared by centrifuging the inoculated broth at $4000 \mathrm{rpm}$ for 10 minutes and pellet was resuspended in PBS and optical density (OD) was set at $590 \mathrm{~nm}$ wavelength with 0.5 McFarland standard. The prepared antigen was taken against the sample serum and $50 \mu \mathrm{l}$ was added from well no. 1 to 10 of the micro titer plate. $4 \mathrm{HU}$ of the compliment was added from well no. 1 to 11 and the microtiter plate was incubated for 40 minutes at a temperature of $37^{\circ} \mathrm{C}$. From well no. 1 to well no. 12 sensitized sheep RBC were added and $4^{\circ} \mathrm{C}$ overnight incubation was provided to the plate. The highest dilution of the each serum sample showing no hemolysis was recorded. Similarly CFT test was carried out for all the fish serum samples. Statistical differences between immune response of vaccine were analyzed by analysis of variance using Tukey's multiple comparison tests for significance. Probabilities of 0.05 or less were considered significantly different. Data was analyzed in statistical programming language R version 4.0.3 using RStudio software.

\subsection{Challenge study}

On the $60^{\text {th }}$ day of post-vaccination, challenge study was done in order to test the degree of protection in all species. L. rohita (Rohu), C. mrigala (Mori) and C. idella (Grass carp) with average weight $305.7 \pm 45$ grams, $291.7 \pm 29$ grams and $328.6 \pm 11$ grams respectively were maintained in glass aquaria in Fish hatchery, UVAS Ravi Campus, Pattoki. Three (03) vaccinated groups (for each vaccine) and a control group were established and stocked with twelve (12) fish ( 4 from each species). The fish were fed daily to satiation with commercially prepared feed. The temperature of water was maintained at $26.5 \pm 1.0^{\circ} \mathrm{C}$ during the observation period.

The challenge study was comprised of A. hydrophila infection of $1 \times 10^{8} \mathrm{CFU} / \mathrm{ml}$ potency to be used for 6 hours through immersion. All fish were starved for 24 hours prior to challenge. Fish were challenged in triple replicated glass aquariums by immersing twelve (12) fish in 6L of virulent bacterial suspension for 6 hours. Continuous and vigorous aeration arrangement was made under controlled temperature during challenge study. After challenging period, fish were shifted to rearing aquariums in which feeding was restarted after three days post challenge. The fish were daily monitored for 2 weeks post-challenge for mortality, lesions formation or any symptom of abdominal 
dropsy. The cause of death was confirmed by isolation of bacteria from gills, liver and kidneys. The relative percent survival (RPS) was determined by using the following formula (Amend, 1981).

\subsection{Histopathology}

On 60 DPV, one fish per treatment per species was dissected. The liver, kidneys, intestine and gills of fish were extracted aseptically and preserved in $10 \%$ formalin. At first, samples were washed with water for an hour then run in $70 \%, 80 \%, 90 \%$ and $100 \%$ alcohol for 2 hours and further soaked with xylene for 20-30 minutes. Xylene was replaced with $50 \%$ xylene and $50 \%$ soft paraffin for 2 hours at $60^{\circ} \mathrm{C}$ in the oven. Soft paraffin was replaced with hard paraffin and kept in oven at $60^{\circ} \mathrm{C}$ for 24 hours. The ribbons of tissues were ripped in distinct portions and placed on the albumenized glass slides. The glass slides were dried for 15 minutes at $60-68^{\circ} \mathrm{C}$ in incubator. The staining of slides was carried out by using Eosin stains and Hematoxylin.

Harris staining method was followed to stain the slides. Slides were kept perpendicularly in the incubator (Memmert Inc.) at $60^{\circ} \mathrm{C}$ for 20 minutes in order to remove the wax from the tissues section. The glass slides were treated with Xylene for 2 minutes and treated with ethanol at $100 \%, 90 \%$ and $70 \%$ for 1 minute each time. Neutralization of slides was carried out with $1 \% \mathrm{NH}_{4} \mathrm{OH}$ for 1 minute then then flooded in running water for 60 seconds. The slides were immersed in $70 \%$ ethanol for 60 seconds. The staining was carried out by using the counter Eosin (Fluka) for 4 minutes. Slides were desiccated with alcohol for 10 seconds. DPX (Di-n-Butyle Phthalate with Xylene) mount was used for mounting the slides.

\section{Results}

Antibody titers of all fish immunized with alumprecipitated vaccines of $10^{8} \mathrm{CFU} / \mathrm{ml}(\mathrm{VA}), 10^{\circ} \mathrm{CFU} / \mathrm{ml}(\mathrm{VB})$ and $10^{10} \mathrm{CFU} / \mathrm{ml}(\mathrm{VC})$ respectively were recorded during CFT procedure. The antibody geometric mean titers (GMT) value and standard deviations were calculated for each sample. Antibody geometric mean titer (GMT) values were plotted on line graphs with respect to DPV to obtain immunokinetics. Antibody titers were maximum at 35 DPV and gradually started to fall afterwards. The immunokinetics showing antibody geometric mean titers (GMT) of $L$. rohita, C. mrigala and C. idella for VA, VB and VC are depicted in Figure 1, Figure 2 and Figure 3 respectively.

After 10 days of post challenge, mortality ratio was $8 \%$ for VA and $17 \%$ for both VB and VC. The protection level (RPS) was $71 \%$ at 60 DPV for VB and VC while $86 \%$ at 60 DPV for VA (Table 1). Therefore, more and long lasting protection against $A$. hydrophila is developed due to VA. The mortality ratio in control group was 58\%. The clinical signs of disease such as petechiae and hemorrhages on body surface were observed in affected fish starting from $4 \mathrm{DPC}$ (days post challenge). The diagnosis of $A$. hydrophila infection was confirmed by isolation of samples from the liver and kidney of moribund fish.

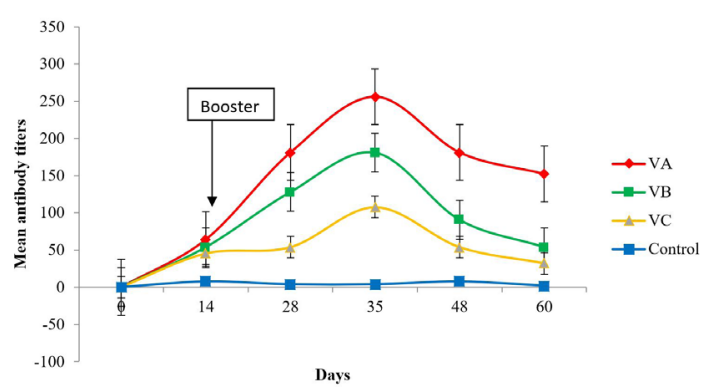

Figure 1. Immunokinetics of $L$. rohita to alum-precipitated vaccines against $A$. hydrophila given on Day 0 and Day 15 (Booster) with $\mathrm{VA}=10^{8} \mathrm{CFU} / \mathrm{ml} ; \mathrm{VB}=10^{9} \mathrm{CFU} / \mathrm{ml}$ and $\mathrm{VC}=10^{10} \mathrm{CFU} / \mathrm{ml}$ dose. Bars indicate \pm SEM (standard error of mean).

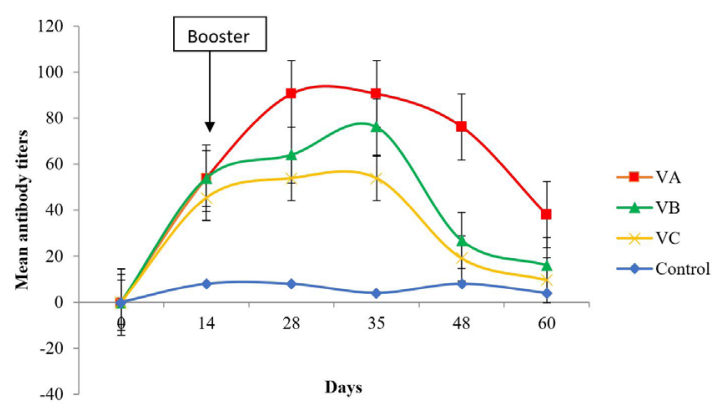

Figure 2. Immunokinetics of $C$. mrigala to alum-precipitated vaccines against $A$. hydrophila given on Day 0 and Day 15 (Booster) with $\mathrm{VA}=10^{8} \mathrm{CFU} / \mathrm{ml} ; \mathrm{VB}=10^{9} \mathrm{CFU} / \mathrm{ml}$ and $\mathrm{VC}=10^{10} \mathrm{CFU} / \mathrm{ml}$ dose. Bars indicate \pm SEM (standard error of mean).

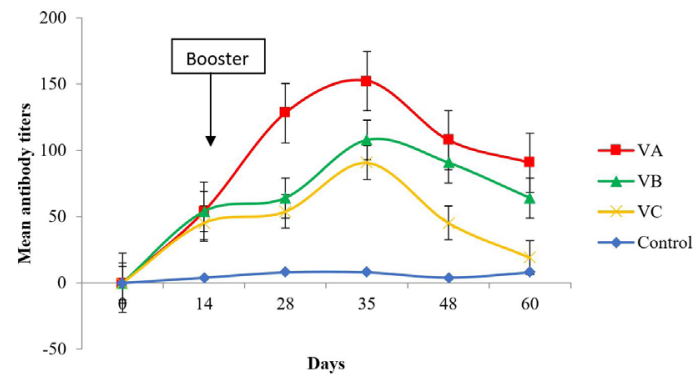

Figure 3. Immunokinetics of $C$. idella to alum-precipitated vaccines against $A$. hydrophila given on Day 0 and Day 15 (Booster) with $\mathrm{VA}=10^{8} \mathrm{CFU} / \mathrm{ml} ; \mathrm{VB}=10^{9} \mathrm{CFU} / \mathrm{ml}$ and $\mathrm{VC}=10^{10} \mathrm{CFU} / \mathrm{ml}$ dose. Bars indicate \pm SEM (standard error of mean).

\subsection{Statistical analysis}

The results of statistical analysis are provided in Table 2. GMTs with similar letters in a column are nonsignificantly different. Significantly higher antibody titers were observed in all vaccinated groups as compared to control group at 14, 28, 35, 48 and $60 \mathrm{DPV}$. No significant variations in antibody titers with VA, VB and VC were observed on 14 day post-vaccination. At 28 and 35 DPV, no significant variation is observed between VA and VB. However, VC shows significantly low GMT. At the end of the trial, statistically significant $(\mathrm{p}<0.05)$ variations in 
Table 1. Comparison of Relative Percent Survivability (RPS) in all species challenged with $10^{8} \mathrm{CFU} / \mathrm{ml}$ dose by immersion method.

\begin{tabular}{|c|c|c|c|c|c|c|}
\hline Vaccines & Species & Total fish & No. of deaths & $\begin{array}{l}\text { Mortality ratio } \\
\text { (\%) }\end{array}$ & Protection (\%) & RPS \\
\hline \multirow[t]{3}{*}{ VA } & L. rohita & 12 & 1 & $8 \%$ & $92 \%$ & $86 \%$ \\
\hline & C. mrigala & & 0 & & & \\
\hline & C. idella & & 0 & & & \\
\hline \multirow[t]{3}{*}{ VB } & L. rohita & 12 & 0 & $17 \%$ & $83 \%$ & $71 \%$ \\
\hline & C. mrigala & & 2 & & & \\
\hline & C. idella & & 0 & & & \\
\hline \multirow[t]{3}{*}{ VC } & L. rohita & 12 & 1 & $17 \%$ & $83 \%$ & $71 \%$ \\
\hline & C. mrigala & & 1 & & & \\
\hline & C. idella & & 0 & & & \\
\hline Control & All species & 12 & 7 & $58 \%$ & $42 \%$ & -- \\
\hline
\end{tabular}

Table 2. Statistical results of GMT vs vaccines and GMT vs species: different superscript letters a, b, c in a column indicate significant difference among vaccines and $\mathrm{x}, \mathrm{y}, \mathrm{z}$ in a column indicate significant difference among species.

\begin{tabular}{|c|c|c|c|c|c|c|}
\hline \multirow[b]{2}{*}{ Species } & \multirow[b]{2}{*}{$\mathbf{D P V} \rightarrow$} & \multicolumn{5}{|c|}{$\begin{array}{l}\text { Antibody Geometric Mean Titers (GMT) values of } 3 \text { alum-precipitated vaccines to all three species } \\
\text { (GMT } \pm \text { SD) }\end{array}$} \\
\hline & & 14 & 28 & 35 & 48 & 60 \\
\hline \multirow[t]{3}{*}{ L. rohita } & VA & $64 \pm 0^{\mathrm{ax}}$ & $181.02 \pm 64^{\text {ax }}$ & $256 \pm 0^{\mathrm{ax}}$ & $181.02 \pm 64^{\mathrm{ax}}$ & $152.22 \pm 83.14^{\mathrm{ax}}$ \\
\hline & VB & $53.82 \pm 13.86^{\mathrm{ax}}$ & $128 \pm 69.74^{\mathrm{abx}}$ & $181.02 \pm 64^{\mathrm{abx}}$ & $90.51 \pm 32^{\mathrm{bx}}$ & $53.82 \pm 39.19^{\mathrm{bx}}$ \\
\hline & VC & $45.25 \pm 16^{\mathrm{ax}}$ & $53.82 \pm 13.86^{\mathrm{bx}}$ & $107.63 \pm 27.71^{\mathrm{bx}}$ & $53.82 \pm 13.86^{\mathrm{bx}}$ & $32 \pm 17.44^{\mathrm{bx}}$ \\
\hline \multirow[t]{3}{*}{ C. mrigala } & VA & $53.82 \pm 13.86^{\mathrm{ax}}$ & $90.51 \pm 32^{\mathrm{ax}}$ & $90.51 \pm 32^{\text {ay }}$ & $76.11 \pm 27.71^{\text {ay }}$ & $38.05 \pm 13.86^{\text {ay }}$ \\
\hline & VB & $53.82 \pm 13.86^{\mathrm{ax}}$ & $64 \pm 0^{\mathrm{abx}}$ & $76.11 \pm 27.71^{\text {aby }}$ & $26.91 \pm 6.93^{\text {by }}$ & $16 \pm 8.72^{\text {by }}$ \\
\hline & VC & $45.25 \pm 16^{\mathrm{ax}}$ & $53.82 \pm 13.86^{\mathrm{bx}}$ & $53.82 \pm 13.86^{\text {by }}$ & $19.03 \pm 6.93^{\text {by }}$ & $9.51 \pm 3.46^{\text {by }}$ \\
\hline \multirow[t]{3}{*}{ C. idella } & VA & $53.82 \pm 13.86^{\mathrm{ax}}$ & $128 \pm 69.74^{\mathrm{ax}}$ & $152.22 \pm 55.43^{\mathrm{az}}$ & $107.63 \pm 27.71^{\mathrm{axy}}$ & $90.51 \pm 32^{\text {axy }}$ \\
\hline & VB & $53.82 \pm 13.86^{\mathrm{ax}}$ & $64 \pm 34.87^{\mathrm{abx}}$ & $107.63 \pm 27.71^{\mathrm{abz}}$ & $90.51 \pm 32^{\mathrm{bxy}}$ & $64 \pm 34.87^{\mathrm{bxy}}$ \\
\hline & VC & $45.25 \pm 16^{\mathrm{ax}}$ & $53.82 \pm 13.86^{\mathrm{bx}}$ & $90.51 \pm 32^{\mathrm{bz}}$ & $45.25 \pm 20.78^{\mathrm{bxy}}$ & $19.03 \pm 10.39^{\text {bxy }}$ \\
\hline All sp. & Control & $4 \pm 2^{\mathrm{b}}$ & $8 \pm 2^{c}$ & $4 \pm 1^{\mathrm{c}}$ & $4 \pm 2^{c}$ & $8 \pm 4^{c}$ \\
\hline
\end{tabular}

antibody titers were recorded for VA as compared to VB and VC. With respect to species, no significant difference in antibody titers was observed at 14 and 28 DPV in three species. However, significantly different $(\mathrm{p}<0.05)$ antibody titers were observed at 35, 48 and 60 DPV. L. rohita and C. idella immune response was not significantly different; however $C$. mrigala exhibited significantly weaker immune response.

\subsection{Histopathology}

Photomicrographs of liver, kidneys, intestine and gills at 60 DPV were recorded from one fish per species in each vaccinated group and control group. Selected photomicrographs showing mild to significant visual observations in different groups and species are shown in Figure 4. The histopathology revealed no significant adverse effect on organs of fish vaccinated with VA and VB (Figure 4A, E, F). However, fish vaccinated with VC (higher concentration of vaccine) caused mild degenerations in liver of $C$. mrigala (Figure 4D). In control group, mild to significant pathological variations were observed due to naturally occurring infections of A. hydrophila (Figure 4B, C).

\section{Discussion}

Fish diseases are becoming devastating factor especially in developing countries like Pakistan, where aquaculture is operational with limited financial and technological resources. One of the constraints faced in major carp culture in Pakistan is the high temperature and humidity during Monsoon season, which provides a favorable environment for $A$. hydrophila to grow in ponds resulting in high risk of fish infections (Kousar et al., 2020). Keeping in view the increasing importance of vaccination as immunoprophylaxis measure for disease prevention, the present study was planned to develop alum-based inactivated vaccines against pathogenic $A$. hydrophila for cultured fish species of Pakistan. Three concentrations of inactivated vaccine $\left(10^{8}, 10^{9}\right.$ and $\left.10^{10} \mathrm{CFU} / \mathrm{ml}\right)$ were 


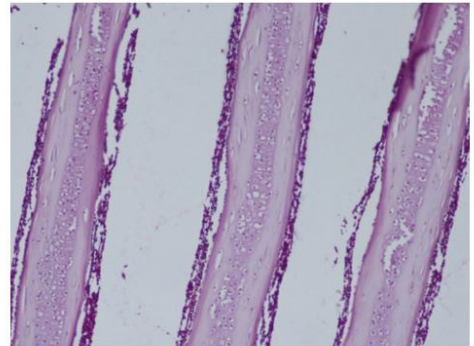

(A)

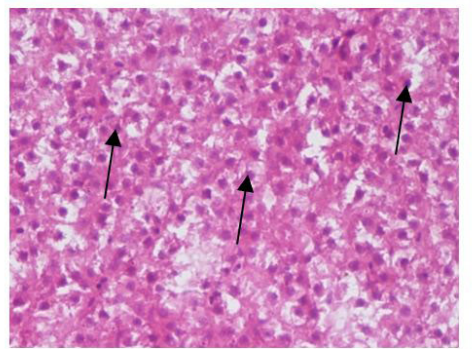

(D)

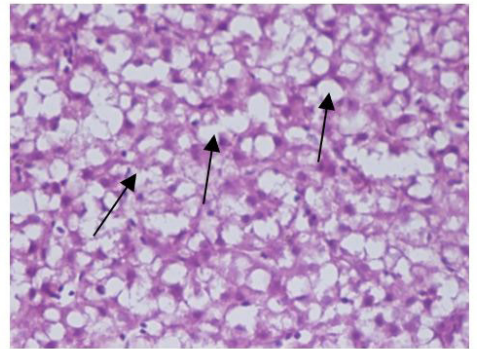

(B)

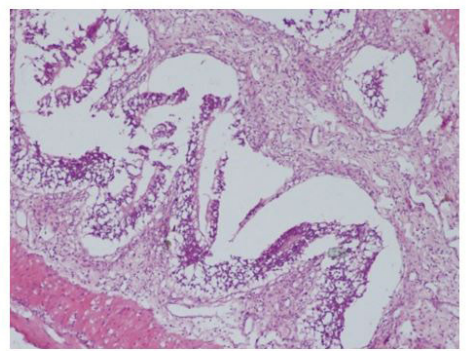

(E)

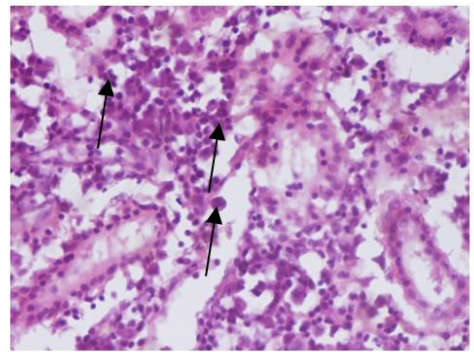

(C)

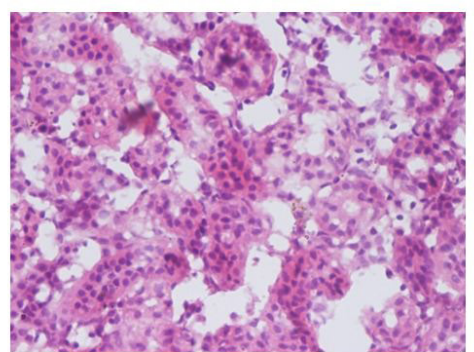

(F)

Figure 4. (A) Gills of C. idella immunized with VA $\left(10^{8} \mathrm{CFU} / \mathrm{ml}\right)$ showing normal gill structure (X10); (B) Liver of C. mrigala in Control group showing majority of the hepatocytes in the hepatic cords vacuolated and swollen (X40); (C) Kidney of L. rohita in Control group showing minor degeneration and necrosis in the renal epithelial cells (X40); (D) Liver of C. idella immunized with VC (10 $\left.{ }^{10} \mathrm{CFU} / \mathrm{ml}\right)$ showing some cells in the hepatic cords undergoing cellular swelling. Majority of hepatocytes are normal is shape and size (X40); (E) Normal intestine in L. rohita from vaccinated group injected with VA $\left(10^{8} \mathrm{CFU} / \mathrm{ml}\right)(\mathrm{X} 10)$; (F) Kidney in C. idella from immunized with $\mathrm{VB}\left(10^{9} \mathrm{CFU} / \mathrm{ml}\right)$ showing almost normal renal parenchyma (X40).

prepared from local A. hydrophila isolate collected from diseased $L$. rohita. In the past, inactivated (formalin-killed) vaccines have been providing reasonable defense against homologous strain of A. hydrophila (Fang et al., 2004). Many studies provided promising results which suggest that vaccination against $A$. hydrophila is possible in culture systems of South Asia (Shome and Shome, 2005; Prasad and Areechon, 2010). Similarly, the vaccine for A. hydrophila in Rainbow trout (Oncorhynchus mykiss) also provided encouraging results (LaPatra et al., 2010).

Studies suggest that most of the commercial fish vaccines are killed whole-cell preparations injected by intraperitoneal route as these are more stable under practical circumstances and may be economical to produce at mass scale (Ma et al., 2019). The results from the present study indicate that inactivated vaccines provide adequate immunity against $A$. hydrophila infection in Indian carps (Rohu and Mori) and Chinese carp species (Grass carp) by intraperitoneal injection. This is in congruence with recent literature reports, such as experiments of Farias et al. (2020) about induction of immune response in Piaractus mesopotamicus against formalin-killed $A$. hydrophila vaccine administered by intraperitoneal (I.P.) route. The result indicated significantly higher serum antibodies in the vaccinated groups as compared to unvaccinated group. Aly et al. (2015) found that formalin-killed vaccine against $A$. hydrophila increases the resistance of Nile tilapia to Aeromonas infection and consequently improves the fish survival. Considering pathogenic species other than A. hydrophila, the result of Suanyuk and Itsaro (2011) indicated that a formalin-killed vaccine provided excellent effectiveness against S. iniae infection in tilapia by intraperitoneal injection.

The inclusion of different cultured fish species in present work has enabled us to investigate impact of vaccine's potency on immune response of different species cultured together. Our findings have close similarity with the existing reports which claim that a particular type of vaccine and vaccination strategy against $A$. hydrophila may induce different immune responses and subsequent protection among different fish species. For instance, John et al. (2002) demonstrated significantly higher superoxide anion production by head kidney leukocytes in C. catla as compared to L. rohita and C. mrigala when immunized with formalin-killed and heat-killed A. hydrophila vaccines.

The protection of immunized fish is variable among and within the Indian major carps. Chandran et al. (2002) conducted formalin-killed vaccine trial of Catfish, C. catla and C. mrigala by two administration routes in which RPS of C. mrigala was observed to be higher than that of C. catla and Catfish. Kalita et al. (2006) observed high RPS value in $C$. catla followed by $L$. rohita and C. mrigala when vaccinated with heat-killed vaccine of $A$. hydrophila with $1 \times 10^{8}$ cells $/ \mathrm{ml}$ potency using immersion bath. Present study shows that $L$. rohita responded with highest serum antibody production and mounted significant protection against challenge with virulent $A$. hydrophila followed by C. idella and C. mrigala. Similarly, in challenge study high RPS values were achieved for $L$. rohita on challenge at potency of $10^{9} \mathrm{CFU} / \mathrm{ml}$ through immersion bath. Different investigators have reported similar antibody response and 
acquired immunogenic potential of fish to A. hydrophila (Prasad and Areechon, 2010; Aly et al., 2015).

Efficacy of vaccines with respect to different concentrations has previously been studied. Kozinska and Guz (2004) has compared the efficacy of multiple vaccines against $A$. bestiarum including formalin-killed whole cell, formalin-killed whole culture and lipopolysaccharide in crude form. Non-specific cellular and humoral parameters of carp ( $C$. carpio $L$.) were observed to define the association between the type of antigen and protective immunity of experimentally infected fish with live bacteria. Recently, Yan et al. (2018) prepared Edwardsiella tarda ghost (ETG) and checked at different concentration levels in vaccination trial. The results showed that serum antibody (IgM) titers were significantly higher in three different concentrations of the vaccinated groups as compared to unvaccinated group. However, no significant difference was observed between the vaccinated groups. It is also claimed that no significant difference in RPS was observed when three different concentrations of ETG were used. In contrast, our study finds that different concentrations of vaccines have produced different effects on antibody titers in trial experiment and RPS in challenge experiment. This suggests further experiments to investigate the relationship between vaccine potency and dose adjustment.

Aluminum compounds are widely used adjuvants in veterinary vaccines for many decades due to their safety, low cost and adjuvanticity with many antigens (Gupta, 1998; Lindblad, 2004). Our study employs potassiumaluminum sulphate as adjuvant to enhance efficacy of vaccines while ensuring safety. Both in vitro and in vivo studies suggest that immunization with alum induces recruitment of various subsets of leukocytes (neutrophils, eosinophils, macrophages and monocytes) at injection site which enhance antigen presenting cells activation and maturation (Ghimire, 2015). This was evident from mild inflammation observed on the injection sites in many fish during present study.

Although vaccine delivery methods have different pros and cons with respect to protective immunity, side effect, practicality and cost effectiveness, it is broadly accepted that injection and immersion routes provide sufficient protection and therefore stand as the primary routes of fish vaccine administration in commercially available vaccines (Muktar et al., 2016). A recent review suggests that vaccinating by I.P. injection in tilapia has provided stronger immune protection than other delivery systems thus far (Shirajum Monir et al., 2020). Application of vaccine by I.P. injection with $A$. salmonicida allowed a survivial rate of $100 \%$ which turned out to be the most protective vaccination method as compared to immersion and feed in a latest research (Schulz et al., 2020). In our study, higher protection and better immune response via intraperitoneal route (I.P.) can be due to direct and proper presentation of bacterial antigens to the immune system which is also documented by Shome and Shome (2005).

In order to evaluate the immunity in fish, the estimation of agglutinating titer is a simple perspective for evaluation of the antibody in serum sample isolated from vaccinated fish (Sugahara and Eguchi, 2012). Agglutinating antibody titer can assess the antibody of immunized fish from the serum (Biller-Takahashi et al., 2014). Although assessment of antibodies has been regarded as an authentic process which can be applied to determine the immune responses, the complement fixation test (CFT) is an appropriate way to observe the immunity developed from inactivated bacteria (Takahashi et al., 2014). It is a lengthy, but dependable way for the serological analysis of the infectious disease caused by pathogens. A CFT was performed in 96-wells microplate according to the method described by (CoronaVargas et al., 2016). Briefly, whole cells A. hydrophila were used as antigen (Ag). 100\% hemolysis was regarded with two units of complement (UC), and two hemolysis units in Triethanolamine Buffer Solution (TBS), pH 7.2. The results of present study are in accordance with these findings in which CFT method is much more sensitive for the detection of antibodies against $A$. hydrophila in selected carp families included in our study.

Vaccine research requires an array of pathological and immunological detection assays for the evaluation of immunogenic potential (Deshmukh et al., 2013). Following the immunization and before challenge, the histopathology of vital organs of vaccinated and unvaccinated fish was studied for signs of adverse reactions due to vaccination. No significant adverse effect was observed in organs of fish vaccinated with $\mathrm{VA}\left(10^{8} \mathrm{CFU} / \mathrm{ml}\right)$ and $\mathrm{VB}\left(10^{9} \mathrm{CFU} / \mathrm{ml}\right)$. However, fish vaccinated with $\mathrm{VC}\left(10^{10} \mathrm{CFU} / \mathrm{ml}\right)$ presented minor degenerations in liver and kidney histology. These findings further suggest adjustment in vaccine concentration and dosage with respect to fish age (size). Manifestations of infection in fish were previously observed in Atlantic salmon using histopathology after vaccination with F. psychrophilum formalin killed vaccine (Hoare et al., 2019). The inflammatory cell infiltrations near outer pancreas, polymorphic inflammatory cells near outer spleen and inflammatory cell infiltrations in injection site and intestine were observed through histology of vaccinated fish. In present study, the fish from control group presented deteriorative alterations in liver, kidney and gills possibly due to naturally occurring $A$. hydrophila infection present in water dominated by the factors such as stress and change in environmental conditions. Interestingly, vaccinated fishes remained protected from such factors. These findings are in congruence with a previous study from India in which histopathological findings in P. hypophthalmus showed normal architecture of the gills, liver and kidney after oral A. hydrophila vaccination. However, fishes in control group, resulted several histopathological abnormalities in all the organs (Mamun et al., 2020).

The overall results observed in this experiment are promising since inactivated vaccines against $A$. hydrophila administered through intraperitoneal route could increase immunogenic potential of mainly cultured fish species against motile aeromonas septicaemia (MAS). This study is a premier step towards development and use of fish vaccines in Pakistan which is based on evaluation of specific antibody titers in blood of cultured fish species (Rohu, Mori and Grass carp) against A. hydrophila and presents the first description of the adaptive immune response of Pakistani cultured fish after vaccination by I.P. route and subsequent challenge via immersion. 


\section{Acknowledgements}

We acknowledge Pakistan Science Foundation (PSF) for providing financial support for the research project on development of vaccines for aquaculture. The work presented in this paper is part of a project sponsored by Pakistan Science Foundation (PSF) under grant no. PSF/ NSLP/P-UVAS(701). We express our gratitude to Quality Operation Lab and Parasitology Lab, UVAS for providing the assistance for conducting microbiological research work in this project.

\section{References}

ABOYADAK, I., ALI, N., GODA, A., ABOELGALAGEL, W. and SALAM, A., 2015. Molecular detection of Aeromonas hydrophila as the main cause of outbreak in tilapia farms in Egypt. Journal of Aquaculture and Marine Biology, vol. 2, no. 6, pp. 00045. http:// dx.doi.org/10.15406/jamb.2015.02.00045.

ADAMS, A., 2019. Progress, challenges and opportunities in fish vaccine development. Fish $\mathcal{E}$ Shellfish Immunology, vol. 90, pp. 210-214. http://dx.doi.org/10.1016/j.fsi.2019.04.066. PMid:31039441.

ALY, S.M., ALBUTTI, A.S., RAHMANI, A.H. and ATTI, N.M., 2015. The response of New-season Nile tilapia to Aeromonas hydrophila vaccine. International Journal of Clinical and Experimental Medicine, vol. 8, no. 3, pp. 4508-4514. PMid:26064376.

AMEND, D.F. 1981. Potency testing of fish vaccines. Fish Biologics: Serodiagnostics and Vaccines, pp. 447-454.

BAUMGARTNER, W.A., FORD, L. and HANSON, L., 2017. Lesions caused by virulent Aeromonas hydrophila in farmed catfish (Ictalurus punctatus and I. punctatus $\times I$. furcatus) in Mississippi. Journal of Veterinary Diagnostic Investigation, vol. 29, no. 5, pp. 747-751. http://dx.doi.org/10.1177/1040638717708584. PMid:28482758.

BEDEKAR, M.K., KOLE, S. and TRIPATHI, G., 2020. Biotechnological approaches to fish vaccine. In: Y.S. MALIK, D. BARH, V. AZEVEDO and S.M.P. KHURANA, eds. Genomics and biotechnological advances in Veterinary, Poultry, and Fisheries, ed. London: Elsevier, pp. 407-419. http://dx.doi.org/10.1016/B978-0-12816352-8.00017-5.

BILLER-TAKAHASHI, J.D., MONTASSIER, H., TAKAHASHI, L. and URBINATI, E., 2014. Proposed method for agglutinating antibody titer analysis and its use as indicator of acquired immunity in pacu, Piaractus mesopotamicus. Brazilian Journal of Biology = Revista Brasileira de Biologia, vol. 74, no. 1, pp. 238-242. http:// dx.doi.org/10.1590/1519-6984.21312. PMid:25055109.

CHANDRAN, M.R., ARUNA, B.V., LOGAMBAL, S.M. and MICHAEL, R.D., 2002. Immunisation of Indian major carps against Aeromonas hydrophila by intraperitoneal injection. Fish E Shellfish Immunology, vol. 13, no. 1, pp. 1-9. http://dx.doi.org/10.1006/ fsim.2001.0374. PMid:12201649.

COLLINS, C., LORENZEN, N. and COLLET, B., 2019. DNA vaccination for finfish aquaculture. Fish \& Shellfish Immunology, vol. 85, pp. 106-125. http://dx.doi.org/10.1016/j.fsi.2018.07.012. PMid:30017931.

CORONA-VARGAS, J.L., VICENCIO-MALLÉN, M.A., SALMERÓNSOSA, F., CARRILLO-CASAS, E.M., TRIGO-TAVERA, F.J. and MIRANDA-MORALES, R.E., 2016. Detection of Antibodies against Mycoplasma mycoides subsp. capri in Goats with the Complement Fixation Test. Advances in Applied Microbiology, vol. 6, no. 13, pp. 959-964. http://dx.doi.org/10.4236/aim.2016.613090.
DASH, P., SAHOO, P., GUPTA, P., GARG, L. and DIXIT, A., 2014. Immune responses and protective efficacy of recombinant outer membrane protein $\mathrm{R}$ (rOmpR)-based vaccine of Aeromonas hydrophila with a modified adjuvant formulation in rohu (Labeo rohita). Fish E'Shellfish Immunology, vol. 39, no. 2, pp. 512-523. http://dx.doi.org/10.1016/j.fsi.2014.06.007. PMid:24937805.

DESHMUKH, S., KANIA, P.W., CHETTRI, J.K., SKOV, J., BOJESEN, A.M., DALSGAARD, I. and BUCHMANN, K., 2013. Insight from molecular, pathological, and immunohistochemical studies on cellular and humoral mechanisms responsible for vaccine-induced protection of rainbow trout against Yersinia ruckeri. Clinical and Vaccine Immunology; CVI, vol. 20, no. 10, pp. 1623-1641. http:// dx.doi.org/10.1128/CVI.00404-13. PMid:23966555.

FANG, H.M., GE, R. and SIN, Y.M., 2004. Cloning, characterisation and expression of Aeromonas hydrophila major adhesin. Fish $\mathcal{E}$ Shellfish Immunology, vol. 16, no. 5, pp. 645-658. http://dx.doi. org/10.1016/j.fsi.2003.10.003. PMid:15110338.

FARIAS, T.H.V., ARIJO, S., MEDINA, A., PALA, G., PRADO, E.J.R., MONTASSIER, H.J., PILARSKI, F. and BELO, M.A.A., 2020. Immune responses induced by inactivated vaccine against Aeromonas hydrophila in pacu, Piaractus mesopotamicus. Fish E Shellfish Immunology, vol. 101, pp. 186-191. http://dx.doi.org/10.1016/j. fsi.2020.03.059. PMid:32247044.

FERNANDEZ, J.B., YAMBOT, A.V. and ALMERIA, O., 2014. Vaccination of Nile tilapia (Oreochromis niloticus) using lipopolysaccharide (LPS) prepared from Aeromonas hydrophila. International Journal of Fauna and Biological Studies, vol. 1, no. 4, pp. 1-3.

FOOD AGRICULTURE ORGANIZATION - FAO, 2018 [viewed 16 March 2021]. The State of World Fisheries and Aquaculture: meeting the sustainable development goals (Vol. License: CC BY-NC-SA 3.0 IGO, pp. 210). Rome: FAO. Available from: http://www.fao. org/3/i9540en/i9540en.pdf.

GHIMIRE, T.R., 2015. The mechanisms of action of vaccines containing aluminum adjuvants: an in vitro vs in vivo paradigm. SpringerPlus, vol. 4, no. 1, pp. 181-181. http://dx.doi.org/10.1186/ s40064-015-0972-0. PMid:25932368.

GUDDING, R. and VAN-MUISWINKEL, W.B., 2013. A history of fish vaccination: science-based disease prevention in aquaculture. Fish EShellfish Immunology, vol. 35, no. 6, pp. 1683-1688. http:// dx.doi.org/10.1016/j.fsi.2013.09.031. PMid:24099805.

GUPTA, R.K., 1998. Aluminum compounds as vaccine adjuvants. Advanced Drug Delivery Reviews, vol. 32, no. 3, pp. 65-89. http:// dx.doi.org/10.1016/S0169-409X(98)00008-8.

HAMOUDA, A., MOUSTAFA, E. and ZAYED, M., 2019. Overview on the most prevailing bacterial diseases infecting Oreochromis niloticus at Aswan fish hatchery, Egypt. Advances in Animal and Veterinary Sciences, vol. 7, no. 11, pp. 950-961. http://dx.doi. org/10.17582/journal.aavs/2019/7.11.950.961.

HOARE, R., JUNG, S.-J., NGO, T.P., BARTIE, K., BAILEY, J., THOMPSON, K.D. and ADAMS, A., 2019. Efficacy and safety of a non-mineral oil adjuvanted injectable vaccine for the protection of Atlantic salmon (Salmo salar L.) against Flavobacterium psychrophilum. Fish \& Shellfish Immunology, vol. 85, pp. 44-51. http://dx.doi. org/10.1016/j.fsi.2017.10.005. PMid:29017943.

IGBINOSA, I.H., IGUMBOR, E.U., AGHDASI, F., TOM, M. and OKOH, A.I., 2012. Emerging Aeromonas species infections and their significance in public health. TheScientificWorldJournal, vol. 2012, pp. 625023. http://dx.doi.org/10.1100/2012/625023. PMid:22701365.

JOHN, M.B., CHANDRAN, M.R., ARUNA, B.V. and ANBARASU, K., 2002. Production of superoxide anion by head-kidney leucocytes of Indian major carps immunised with bacterins of Aeromonas 
hydrophila. Fish E Shellfish Immunology, vol. 12, no. 3, pp. 201207. http://dx.doi.org/10.1006/fsim.2001.0365. PMid:11931016.

KALITA, B., MOHAN, C., SHANKAR, K. and AZAD, I., 2006. Humoral and protective response of Indian major carps to immersion vaccination with Aeromonas hydrophila. Journal of Indian Fisheries Association, vol. 33, pp. 161-168.

KOUSAR, R., SHAFI, N., ANDLEEB, S., ALI, N.M., AKHTAR, T. and KHALID, S., 2020. Assessment and incidence of fish associated bacterial pathogens at hatcheries of Azad Kashmir, Pakistan. Brazilian Journal of Biology = Revista Brasileira de Biologia, vol. 80, no. 3, pp. 607-614. PMid:31644654.

KOZINSKA, A. and GUZ, L., 2004. The effect of various Aeromonas bestiarum vaccines on non-specific immune parameters and protection of carp (Cyprinus carpio L.). Fish \& Shellfish Immunology, vol. 16, no. 3, pp. 437-445. http://dx.doi. org/10.1016/j.fsi.2003.08.003. PMid:15123310.

LAPATRA, S.E., PLANT, K., ALCORN, S., OSTLAND, V. and WINTON, J., 2010. An experimental vaccine against Aeromonas hydrophila can induce protection in rainbow trout, Oncorhynchus mykiss (Walbaum). Journal of Fish Diseases, vol. 33, no. 2, pp. 143151. http://dx.doi.org/10.1111/j.1365-2761.2009.01098.x. PMid:19732266.

LARRY, M. and JAMES, T.P., 2001 [viewed 16 May 2021]. Bacteriological Analytical Manual [online]. Aerobic Plate Count. Available from: https://www.fda.gov/food/laboratory-methods-food/ bacteriological-analytical-manual-bam.

LINDBLAD, E.B., 2004. Aluminium compounds for use in vaccines. Immunology and Cell Biology, vol. 82, no. 5, pp. 497-505. http:// dx.doi.org/10.1111/j.0818-9641.2004.01286.x. PMid:15479435.

MA, J., BRUCE, T.J., JONES, E.M. and CAIN, K.D., 2019. A review of fish vaccine development strategies: conventional methods and modern biotechnological approaches. Microorganisms, vol. 7, no. 11, pp.569. http://dx.doi.org/10.3390/microorganisms7110569. PMid:31744151.

MAMUN, M., NASREN, S., ABHIMAN, P., RATHORE, S., SOWNDARYA, N., RAMESH, K. and SHANKAR, K., 2020. Effect of biofilm of Aeromonas Hydrophila oral vaccine on growth performance and histopathological changes in various tissues of Striped Catfish, Pangasianodon Hypophthalmus (Sauvage 1878). Indian Journal of Animal Research, vol. 54, no. 5, pp. 563-569.

MUKTAR, Y., TESFAYE, S. and TESFAYE, B., 2016. Present status and future prospects of fish vaccination: a review. Journal of Veterinary Science \& Technology, vol. 7, no. 2, pp. 1-7. http:// dx.doi.org/10.4172/2157-7579.1000299.

MZULA, A., WAMBURA, P.N., MDEGELA, R.H. and SHIRIMA, G.M., 2019. Current state of modern biotechnological-based Aeromonas hydrophila vaccines for aquaculture: a systematic review. BioMed Research International, vol. 2019, pp. 3768948. http://dx.doi. org/10.1155/2019/3768948. PMid:31467887.

NEIFFER, D.L. and STAMPER, M.A., 2009. Fish sedation, analgesia, anesthesia, and euthanasia: considerations, methods, and types of drugs. ILAR Journal, vol. 50, no. 4, pp. 343-360. http://dx.doi. org/10.1093/ilar.50.4.343. PMid:19949251.

PRASAD, S. and AREECHON, N., 2010. Efficacy of formalin-killed Aeromonas hydrophila and Streptococcus sp. vaccine in red tilapia. Our Nature, vol. 8, no. 1, pp. 231-240. http://dx.doi. org/10.3126/on.v8i1.4333.

PURCELL, R.H., HOLLAND, P.V., WALSH, J.H., WONG, D.C., MORROW, A.G. and CHANOCK, R.M., 1969. A complement-fixation test for measuring Australia antigen and antibody. The Journal of Infectious Diseases, vol. 120, no. 3, pp. 383-386. http://dx.doi. org/10.1093/infdis/120.3.383. PMid:4980772.

RAHMAN, S., SIDDIQUE, M., HUSSAIN, I., MUHAMMAD, K. and RASOOL, M., 2003. Standardization of indirect haemagglutination test for monitoring Mycoplasma mycoides subspecies capri antibodies raised in rabbits and goats. International Journal of Agriculture and Biology, vol. 5, pp. 295-297.

SCHULZ, P., TERECH-MAJEWSKA, E., SIWICKI, A.K., KAZUŃ, B., DEMSKA-ZAKĘŚ, K., ROŻYŃSKI, M. and ZAKĘŚ, Z., 2020. Effect of different routes of vaccination against Aeromonas salmonicida on rearing indicators and survival after an experimental challenge of Pikeperch (Sander lucioperca) in controlled rearing. Vaccines, vol. 8, no. 3, pp. 476. http://dx.doi.org/10.3390/vaccines8030476. PMid:32858831.

SHAH, S.Q., COLQUHOUN, D.J., NIKULI, H.L. and SøRUM, H., 2012. Prevalence of antibiotic resistance genes in the bacterial flora of integrated fish farming environments of Pakistan and Tanzania. Environmental Science E Technology, vol. 46, no. 16, pp. 86728679. http://dx.doi.org/10.1021/es3018607. PMid:22823142.

SHIRAJUM MONIR, M., YUSOFF, S.M., MOHAMAD, A. and INASALWANY, M., 2020. Vaccination of tilapia against Motile Aeromonas Septicemia: a review. Journal of Aquatic Animal Health, vol. 32, no. 2, pp. 65-76. http://dx.doi.org/10.1002/ aah.10099. PMid:32331001.

SHOME, R. and SHOME, B., 2005. Evaluation of three types of Aeromonas hydrophila vaccines against acute infectious dropsy disease in Indian major carps. Indian Journal of Fisheries, vol. 52, no. 4, pp. 405-412.

SOMMERSET, I., KROSSOY, B., BIERING, E. and FROST, P., 2005. Vaccines for fish in aquaculture. Expert Review of Vaccines, vol. 4, no. 1, pp. 89-101. http://dx.doi.org/10.1586/14760584.4.1.89. PMid: 15757476

SUANYUK, N. and ITSARO, A., 2011. Efficacy of inactivated Streptococcus iniae vaccine and protective effect of $\beta-(1$, $3 / 1,6)$-glucan on the effectiveness of vaccine in red tilapia Oreochromis niloticus x O. mossambicus. Songklanakarin Journal of Science and Technology, vol. 33, no. 2, pp. 143-149.

SUGAHARA, K. and EGUCHI, M., 2012. The use of warmed water treatment to induce protective immunity against the bacterial cold-water disease pathogen Flavobacterium psychrophilum in ayu (Plecoglossus altivelis). Fish E'Shellfish Immunology, vol. 32, no. 3, pp. 489-493. http://dx.doi.org/10.1016/j.fsi.2011.12.005. PMid:22209763.

TAKAHASHI, E., OZAKI, H., FUJI, Y., KOBAYASHI, H., YAMANAKA, H., ARIMOTO, S., NEGISHI, T. and OKAMOTO, K., 2014. Properties of Hemolysin and Protease Produced by Aeromonas trota. PLoS One, vol. 9, no. 3, pp. e91149. http://dx.doi.org/10.1371/journal. pone.0091149. PMid:24633045.

VECCHI, S., BUFALI, S., SKIBINSKI, D.A., O'HAGAN, D.T. and SINGH, M., 2012. Aluminum adjuvant dose guidelines in vaccine formulation for preclinical evaluations. Journal of Pharmaceutical Sciences, vol. 101, no. 1, pp. 17-20. http://dx.doi.org/10.1002/ jps.22759. PMid:21918987.

YAN, M., LIU, J., LI, Y., WANG, X., JIANG, H., FANG, H., GUO, Z. and SUN, Y., 2018. Different concentrations of Edwardsiella tarda ghost vaccine induces immune responses in vivo and protects Sparus macrocephalus against a homologous challenge. Fish E' Shellfish Immunology, vol. 80, pp. 467-472. http://dx.doi. org/10.1016/j.fsi.2018.06.034. PMid:29928994. 